\title{
Veronica Ghirardi Postmodern Traces and Recent Hindi Novels
}

Thomas Dähnhardt

Università Ca' Foscari Venezia, Italia

Review of Ghirardi, V. (2021). Postmodern Traces and Recent Hindi Novels. Wilmington: Vernon Press, $234 \mathrm{pp}$.

Modern, or rather, post-modern Hindi literature (whatever one intends with this term) surely does not figure among those areas of research that are commonly addressed even by specialist scholars in Indian studies. And even those few who have chosen Hindi literature as their field of specialisation have focused their attention predominantly on earlier literary currents, such as the neo-romantic Chāyāvāda poetry or the post-independence Nayì kahānī that flourished during the late 1950s and the early 1960s of the past century. If anything, the attention of scholars is drawn on a kind of literature produced by minority or marginalised groups within South Asian society, such as Dalits and aboriginals, or Muslim writers adopting Hindi as their medium of expression, all concerned with addressing specific identities on the margins. Hence, because of the relative neglect of literary novels in Hindi in the domain of academic production, the present work by the young Italian scholar Veronica Ghirardi from the outset strikes an innovative note not only because it fills

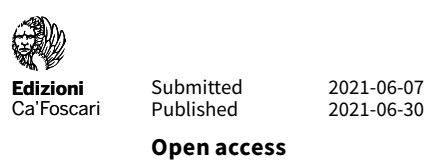

(C) 2021 | ()( Creative Commons Attribution 4.0 International Public License 
a gap in Hindi literature scholarship, but also because it deliberately takes on a complex issue such as exploring elements (or traces, as the title suggests) of post-modernism in contemporary Hindi novels.

The book, the published version of Ghirardi's recently awarded $\mathrm{PhD}$ thesis by the Università degli Studi di Torino, is the final outcome of a research that has taken the author several years exploring the influence of post-modernism as a category relying on Western thought patterns on Indian literature or, more specifically, Hindi novels published in the decade between 1991 and 2001. This is in itself a formidable challenge, for Hindi although being declared by the country's Constitution adopted in 1950 India's official language (rājbhāṣā) alongside English, it is by no means the one Indian language that has adopted without reluctance and difficulties of various kinds the literary genres imported from the Western, viz. British cultural sphere. As a result, the competition with literary productions in English did and still does present a formidable challenge to the emergence of Hindi as a truly national language, a status it does not hold until the present day. All these complicating circumstances notwithstanding, Ghirardi has ventured into this relatively unexplored territory, arguing that postmodernism, characterised by a growing disillusionment with established institutions and social structures, became an influential factor on the Hindi literary sphere after the adoption in the early 1990s of economic policies aimed at liberalising India's hitherto state-controlled economy and open its markets in an unprecedented manner to global corporations and trade. The changed conditions of the country's economy significantly contributed to the transformation of the cultural and literary sphere inducing Hindi as well as authors of other Indian vernaculars to produce narratives reflecting the characteristics of postmodernism in a more self-conscious manner (foreword, p. xxiii). Although recognising the limits of writing in Hindi in a more and more globalised world and Indian cultural sphere, Ghirardi bases her approach on the presumption that the literary novel in general remains a powerful medium for addressing and describing the challenges faced by different social groups around the globe and that this, as far as South Asia is concerned, applies also to the Hindi literary novel during the period under investigation. In order to provide substance to this claim, Ghirardi has singled out altogether twelve contemporary Hindi novels written in the course of the last decade of the 20th century in which she detects post-modern elements liable to an analysis of what this may present and of what its characteristic features may tell us about this particular cultural and literary sphere. So, which are the peculiarities that insert the Hindi novel into the larger context of postmodernism and to what extent do they enhance or enrich the conventional definitions of postmodernism as defined by Western models of thought? These are the central themes addressed by Ghirardi in her book. 
The starting point of Ghiradi's explorations is Hariyā Harkyūlīz kì hairānī, the fourth novel by the author Manohar Śyām Jośi (19332006), best known in India for being the author of the country's first soap opera series Ham log (1984), but recognised as one of the most innovative recent Hindi writers who in his early days had been an assistant of the famous poet Ajñeya (1911-1987), the pioneer of experimentalism (prayogvād) in Hindi literature. This work figures as a sample exemplifying the whole thought of Ghirardi, for in it she distinguishes the principal characterising features of the postmodernist cultural phenomenon: the centrifugal force, i.e. an implicit tendency towards deconstruction of the story as it develops, of its characters and of the places where it is really or ideally located. The initial linear account that reverts around the local narrative of the Kumaoni community in the capital Delhi and its identity (the community to which both the author and the protagonist of the story belong) gradually dissolves in a sequence of ambiguous and multifaceted identities, with no certain outcomes or the definition of an unassailable truth or solution. The story of the protagonist, Hariyā Harkyūlizz, is transformed into multiple single elements, similar to a cubist painting (3), in which one is left with contemplating innumerable elements in manifold perspectives, but with no definite truth emerging from them. The underlying technique to achieve this effect is that of an accompanying intertextuality with references to India's ancient devotional and spiritual traditions as well as more modern ideologies, such as communism and feminism. Ghirardi interconnects this specifically Indian context with similar notions present in other corners of the world, such as Murakama Haruki's works in Japanese literature, as well as, obviously, Anglo-Indian literature, such as the novels by Salman Rushdie who, in a sense, triggered off the whole discussion on postmodernism in literature. To prove that the thought line developed by Ghirardi is not an entirely self-conscious intellectual exercise is the precedent emergence by Indian literary critics concerning the emergence of post-modern elements in Indian vernaculars. Central to Ghirardi's argument in this sense is an article by Sudhish Pachauri, a proficient writer and literary theorist and professor in the Hindi Department and former Vice Chancellor of Delhi University, who in 1996 published the ground-breaking work Uttar-ādhunik sāhityik vimarś (Postmodern Literary Discourse) which proposes a genuine even if derivate Indian interpretation of postmodernism; this was followed more recently by Sanjay Chauhan's Uttar-ädhuniktā air hindī upanyās (Postmodernism and Hindi Novels), to testify to an ongoing debate among India's intellectuals on postmodernism and its applications in the Indian cultural environment in the Hindi language.

Drawing on both Western and Hindi literary șcriticism, Postmodern Traces and Recent Hindi Novels aims at helping the specialist reader to understand some of the reflections of postmodernism in 
contemporary Hindi fiction, including ways the latter might challenge the traditional parameters of postmodern literature. This book provides stimulating reading for scholars and students specialising in South Asian studies and both postcolonial and comparative literature. It will also interest the general reader curious to know more about one of the less explored areas of world literature.

On the whole, the book is thoroughly researched, fuelled by the author's genuine interest in and passion for the subject under investigation. Her good command of the Hindi language allows her to quote, which developed in the course of her research for her PhD thesis. Although the title somewhat blurs the issues at stake (personally, I had rather chosen: Post-Modern Traces in Recent Hindi Novels), the author's quality of scholarship becomes evident in the wide range of works analysed for the purpose of making her point. The many quotations from the original Hindi texts not only betray her sound knowledge of the Hindi language but bear witness to Dr. Ghirardi's capacity to 'read' the Indian mind structure and decode it while inserting it into a western academic discourse. Although not alone in tracing the path (cf., for instance, the Phd thesis by Wattenberger 2012), ${ }^{1}$ the book addresses an interesting and (I imagine) widely appreciated field of investigation, both in South Asia and in the West, and suggests new lines of reading and interpreting a so far somewhat marginal literature which deserves more attention. For those interested in and already familiar with Indian literature, it provides a stimulating and in many ways original way of looking at a kind of literature that too often remains at the margins of attention of the larger public. The merit of the way the book is organized is not only that of addressing the specialised academic scholar familiar with Indian literary traditions, but also the way the topic is addressed and contextualised in attempting to insert the Hindi novel first into the wider context of Indian literature in general and then, even more ambitiously, into world literature in an increasingly globalised society. Though Ghirardi's attempt cannot be but a small however thoughtprovoking contribution set in a huge ocean, it has the unquestionable merit of taking into account and analysing most relevant Hindi novels published in the past thirty years or so, scrutinising their style and content against the parameters of postmodern literature, something the author achieves in both an original and captivating fashion. This recent publication by the American Vernon Press makes a precious addition to all the scholars or passionate readers of Hindi literature. 